\title{
DEMAGOGY OF THE MEDIA: INFORMATION AND/OR MANIPULATION WITHIN SOCIAL MEDIA
}

\section{Demagogia mediów: informacja i/lub manipulacja w mediach społecznościowych}

\begin{abstract}
Demagogy of the media within the virtual perceptual reality of social networks on WWW is information and/or manipulation with the goal of realizing individual and/ or group interests. The social networks which we are using online for information and communication are both the message and the medium. We use it as a classic medium for transmitting, sublimating, creating information with existent feed-back of identical, similar or contradictory intents. The way of presenting us within this media is a kind of message about the intent of the opposing ones but also of those who "follow, read, and communicate with us". When social networks are used for online journalism, we allow more people access in a difference from "classic" journalism and at the same time we have the possibility that, at the time of creation, we have a commentary on the social networks as well as a kind of marketing of our own messages and of our media. Do we live in the virtual world of real social communication with the goal of comprehensive information of our own being, or does that real world of virtual social communication create us as part of the binary code of our own thinking?
\end{abstract}

Keywords: demagogy, information, manipulation, social media, message, journalism, communication, people, control

\begin{abstract}
Abstrakt: Demagogia mediów w wirtualnej rzeczywistości odbioru sieci społecznościowych w sieci WWW to informacja i/lub manipulacja w celu realizacji indywidualnych is lub grupowych interesów. Sieci społecznościowe, których używamy do przekazywania informacji i komunikacji w sieci, stanowiq zarówno komunikat, jak i medium. Używamy ich jako klasycznego medium do przekazywania, sublimacji, oraz tworzenia informacji $z$ istniejacych informacji zwrotnych, o identycznych, podobnych lub sprzecznych intencjach. Sposób prezentowania nas samych w tych mediach to rodzaj przestania o zamysłach osób

1 Assoc. Prof. Dr. And Dr. Honoris Causa Sabahudin Hadžialić, UNINETTUNO University, Rome, Italy, e-mail: sabahudin.hadzialic@uninettunouniversity.net
\end{abstract}


nam przeciwnych, ale także tych, którzy "nas śledza, czytaja i komunikuja się z nami”. Kiedy portale spotecznościowe sa wykorzystywane do dziennikarstwa internetowego, pozwala to dotrzeć do większej liczby osób, w odróżnieniu od "klasycznego" dziennikarstwa, a jednocześnie daje to możliwość komentowania w momencie zamieszczenia na portalu społecznościowym, petni to również rolę reklamy dla naszego własnego przekazu i naszych mediów. Czy żyjemy w wirtualnym świecie prawdziwej komunikacji społecznej, której celem jest zapewnienie nam kompleksowej informacji o naszym wtasnym istnieniu, czy też w rzeczywistym świecie wirtualnej komunikacji społecznej, która definiuje nas jako część binarnego kodu naszego własnego myślenia?

Keywords: demagogia, informacja, manipulacja, media społecznościowe, przestanie, dziennikarstwo, komunikacja, ludzie, kontrola

\section{Introduction}

The aim of the paper is to define the role of social networks on the WWW within the assumption of whether there is any information or manipulation in the reflection of demagogy of the media in virtual perceptual reality:

a) In order to explain the "and/or" the possibility that the media itself is the source of information and / or manipulation to confirm the thesis that "Conspiracy theories do not exist, but it works" (Hadžialić, 2010);

b) In order to establish the fact that even the sincerest ideas for advancing the existence of mankind can become their own opposite (Opennheimer, 1947) with the aim of manipulating the sequence of events that ultimately leads to control of thoughts and actions;

c) In order to detect hidden agendas within the use of information collected from social networks, they are analyzed and manipulated by governing structures with a focus on controlling possible future actions of their own citizens (NSA, 2013);

d) In order to deal with the problem of everyday "bombardment" with excessive and unnecessary flash information that condition certain reactions with the aim of manipulating our consciousness in the direction of assumed intentions in the model and the state of something called social networks as the assumption of total and / or mad/insane (Maciedo, 2013) awareness that, through the social networks, tell us about the end of history we know; 
e) In order to find solutions that in the modern Agora (a central public space in ancient Greek city-states), that could appropriately become the use of social networks, to create preconditions that, avoiding manipulation, we create the possibility of mutual information with the aim of improving everyone's prosperity with the goal everyone for one and one for everyone. No matter how utopian it sounded "Avelange was the snowflake at the beginning" (Hadžialic, 2009) in the space and time where manipulation is the subject of all sorts of information we know, even when we talk about online journalism;

f) In order to present the potential positive role of social networks on the WWW with the aim of realizing the promise of the Internet, that his/ her full incarnation as the individual will be experienced as immediate, at the same time as the creator, participant but also the perpetrator of this/her own guidelines presented on social networks. However, at the level of "communication theory, it complains that the political public on the Internet substantially promotes its privatization, because the individual can use the possibilities again only as an individual and thus avoids the effects of filtering that are coming from the representative public and communication among the present ones" (Mayer, 2003).

\section{Pro et contra of the observation of theoretical framework}

The attractiveness of direct/immediate and many-to-many communications includes its pro, but also cons observations. Namely, within social networking, with the advantages (which are sometimes also flaws, depending on the way of use) that are reflected in:

a) instant, momentary communication of all with everyone;

b) the infinite ability to store information in the unit of time;

c) shaping the desired information without (it is only possible afterwards in the case of obscenities, hatred, racial and gender prejudices, etc.) censor control (Rääbus, 2017);

d) photos, videos, texts, comments, responses generated by our wishes and the freedom of communication,

e) exchange of information with the aim of improving their own knowledge... in front of us lays down the same, if not even the bigger form 
of flaws (which often become the advantages, depending on the mode of use) that are reflected in:

1) manipulation of information through lies, deception, shalf-truths, propaganda within created groups, individual interests, and targeted topics;

2) testing and directing (read: manipulating) public opinion for the needs of certain politicians (Markandey, 2012), group (Keller, 2010) and/or marketing products (DeMers, 2014) through seemingly simple, "innocent and naive" communication panels/riddles.

\section{Demagogy of the media - testing of the assumptions}

Demagogy of the media within the virtual perceptual reality of social networks on the WWW as information and/or manipulation with the goal of realizing individual and/or group interests is interesting starting axiom of possible perceptual responses. Let us go in medias res - from the point of view that the medium is the message (McLuhan, 1967) and in which way we can view social networks within the form of Makluan's assumptions? The social networks we use online for information and / or communication are both the message and the medium. How?

First, we use it as a classic medium for transmitting, sublimating, creating information with existent feed-backs of identical, similar or contradictory intents/purposes. Secondly, the way we present it on the media is a kind of message about the intentional intent/purpose of the opposed ones, but also the ones who thinks like us and "who are following, reading, communicating with us". Thirdly, if we use social networks for online journalism, we allow far more people access to information as opposed to "classical" (old school) journalism and at the same time we have the possibility, through the above-mentioned thesis many to many, that we have, at the time of creation - over the social networks, comment, but also a kind of marketing of our own messages and our media. Social networks are a unique example of unification of information, but also of power within a media that has a "social" prefix. Is that right? Perhaps it is a "social" but "controlled social" medium.

We should outline and explain mentioned with the methodological, clear and concrete examples of practice, but first of all we should bring 
closer, in general, the use of the Internet in 2017. (3.77 billion users): The top five WWW browsers (Google Chrome, Microsoft Edge, Mozilla Firefox, Safari, Opera) cover $98 \%$ of the online community, while only $2 \%$ of the other web browsers belongs to the online community, that, even within the use of social networking, creates a problem: a) Who controls those browsers and pages you visit within social networks (Edwards, 2016); a) How is designed (which information from our surfing collects and to whom it is delivered to); c) To whom social networking information is provided to (Slade, 2014) and how (Bort, 2016).

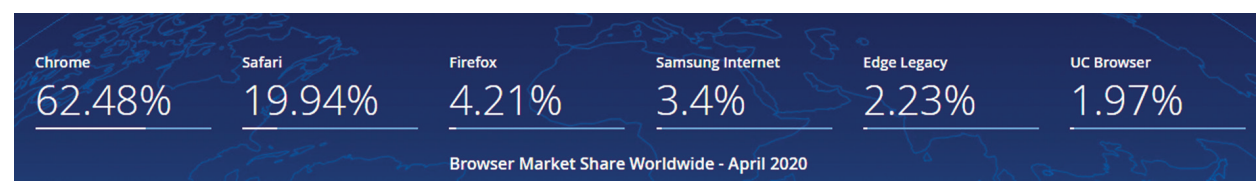

Graphic. 1. Global desktop web browser market share statcounter, April 2020

And we come to numbers that exceed all expectations of the normal (only for someone who does not understand the meaning of communication through the network) understandings within the assumptions of communication: E-mail: There are over 4 billion email users are around the world ${ }^{2}$; - 281 billion email messages were exchanged and received daily in $2018^{3}$.

\subsection{Websites and Web Hosting}

(Hosting Facts, 2019'): 58.8\% of the most visited million pages are based in the United States; • There are even 471.6 million Tumblr blogs as of July 2019, and 77.8. million blogs (2018) blogs at WordPress ${ }^{5}$.

2 WebsiteBuilder, Email marketing stats, https://websitebuilder.org/email-marketing-stats/ - expecting to be at least 4.4. billion users by 2023, (6.04.2020).

3 Ibidem (6.04.2020).

4 N. Galov, 101+ web hosting stats and facts to help choose a better host, https:/ / hostingtribunal.com/blog/web-hosting-statistics/\#gref (6.04.2020).

5 K. Byers, How many blogs are there? (And 141 other blogging stats), https:/ /growthbadger.com/blog-stats/(6.04.2020). 


\section{Internet World Penetration Rates by Geographic Regions - 2020 Q1}

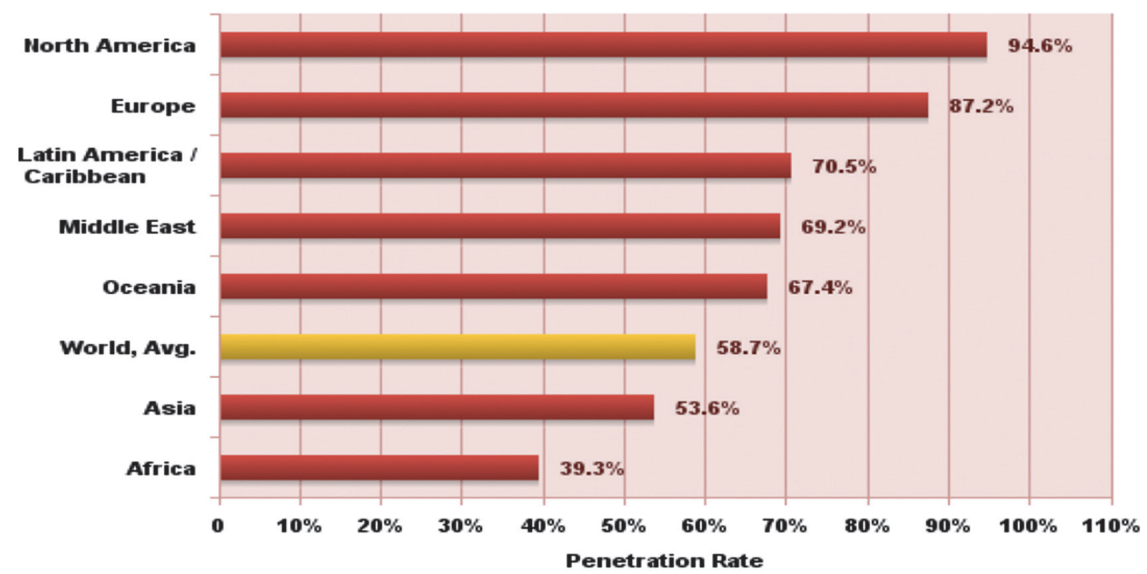

Source: Internet World Stats - www.internetworldstats.com/stats.htm Penetration Rates are based on a world population of $7,796,615,710$ and 4,574,150,134 estimated Internet users in March 3, 2020. Copyright @ 2020, Miniwatts Marketing Group

Graphic 2. Internet World Penetration Rates by geographic regions - 2020 Q1

Domains (Verisign, 2017): There are 184 million domain name registrations across all top-level domains by the end of the second quarter 20096; - The most expensive domain (sex.com) in 2010 was sold for as much as $\$ 13$ million. Internet users: There are as many as $\mathbf{4 . 4 8}$ billion Internet users in the world as of October 20197; • Of this, 2.1 billion comes from Asia ${ }^{8}$; 461 million people access Internet from Europe $; \bullet$ The country with the largest number of internet users in the world is China, which accounts for nearly 875 million $^{10}$. Social networks: The number of active

6 T. Reitnauer, How many domainsare registered in total? Statistics \& numbers, part II, https://iwantmyname.com/blog/how-many-domains-are-registered-in-total (7.04.2020).

7 G. Deyan (2020), How many websites are there in 2021, https://techjury.net/blog/ how-many-websites-are-there/\#gref (7.04.2020).

8 M. Moore, Number of internet users APAC 2020 by country or region, https:/ / www.statista.com/statistics/265153/number-of-internet-users-in-the-asia-pacific-region/ (6.4.2020).

9 Internet World Stats, https://www.internetworldstats.com/stats9.htm (accessed 6.4.2020).

10 L.L. Thomala, Number of internet user in China 2015-2025, https://www.statista. com/statistics/278417/number-of-internet-users-in-china/ (6.04.2020). 
Facebook users in 1st quarter of 2020 are 2.6 billion ${ }^{11}$; • As of April 2020, it was found that ten percent of global active Facebook users were women between the ages of 18 and 24 years, and male users between the ages of 25 and 34 years constituted the biggest demographic group of Facebook users $^{12}$; • Every day it is send 500 million Tweets ${ }^{13}$; • LinkedIn counts as many as 575 million users in $2020^{14}$.

\section{Internet Users Distribution in the World - 2020 Q1}

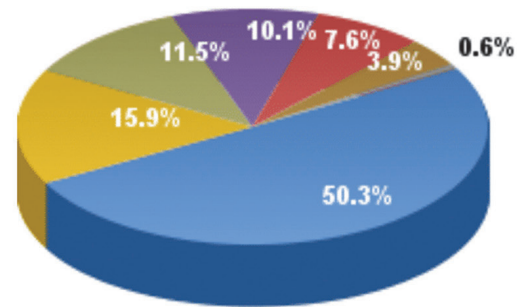

Asia $\mathbf{5 0 . 3} \%$

Europe $15.9 \%$

Africa. 11.5\%

Lat Am / Carib. 10.1\%

North America $7.6 \%$

Middle East $\mathbf{3 . 9} \%$

Oceania / Australia $\mathbf{0 . 6 \%}$

Source: Internet World Stats - www.internetworldstats.com/stats.htm

Basis: 4,574,150,134 Internet users in March 3, 2020

Copyright @ 2020 , Miniwatts Marketing Group

Graphic 3. Internet user distribution in the world - 2020 Q1

\subsection{Mobile}

- Over 4.78 billion mobile phone users around the world ${ }^{15}$; $\bullet 61.5 \%$ of the world's population had a smartphone by April $2020^{16}$.

11 Number of monthly active Facebook users worldwide as of 4th quarter 2020, https:/ / www.statista.com/statistics/264810/number-of-monthly-active-facebook-users-worldwide/ (6.04.2020).

12 Facebook global user age distribution, https://www.statista.com/statistics/376128/ facebook-global-user-age-distribution/ (7.04.2020).

13 Internet Live Stats, Twitter usage statistic, https:/ / www.internetlivestats.com/twitter-statistics/ (7.04.2020).

14 M. Osman, Mind-blowing LinkedIn statistic and facts https:// kinsta.com/blog/linkedin-statistics/ (6.04.2020).

15 Bankmycell, How many phones are in the world, https://www.bankmycell.com/ blog/how-many-phones-are-in-the-world (accessed 7.4.2020).

16 Ibidem (6.04.2020). 
And now we come to the methodological-logical sequence of human survival, where in the center of human's experience of the world and of himself/herself as one of the most important questions the question is raised the question of freedom (From, 1994). Freedom is linked to the existential question about the overcoming of each immediate challenge and the opposition to every misunderstanding, degradation and / or destruction during the course of civilization development (is it? - in the last 100 years has been killed more people than in the past 2000 years). On the social networks are 2.65 billion users from the planet Earth who are sitting in their homes, talking online, reading news online, watching video and movie records, negotiating, falling in love, wrangle, arguing, inviting protests ${ }^{17}$, call for devastation of the governments (Radio Free Europe, 2013) or control by governments towards their own citizens (Otta, Rousseau, 2002). So the question is how close is the real and unreal interaction, and how thin is the line between genius and madman, when it comes exploitation and the (mis)use of social networks? Do we live the virtual world of real social communication with the goal of comprehensive information of our own being, or does that real world of virtual social communication create us as part of the binary code of our own thinking?

\section{The message as the medium of socialization - the medium as the socialization message}

Answers to these methodological questions are not hidden in the cheaply way of everyday life transferred into the virtual world of legitimate constants, but in the media itself or in the message, depending on whose follower are we of the possible media intentions. Namely, the answers are hidden in something entirely different but different. I'm going to be blasphemous, brutally-painfully different: Variable, or, in other words, changeable, in this case, is the message, but also the media that change depending on the perception / recognition mode by the side of communicator but also by the side of the consumer of information. Example: A Facebook message with a photo where you are in a company with a well-known poet and / or journalist

17 Number of social network users worldwide from 2017 to 2025 (in billions), https:/ / www. statista.com/statistics/278414/number-of-worldwide-social-network-users/ (6.04.2020). 
can be differently read by your virtual, but also real (who are that in the real world) friends depending on their social, psychological, gender and / or voyeuristic profile (Grainger, 2017). That is how everything will be read in social networks. Given that we should not omit the most basic assumption that is aimed at understanding of this kind of communication: the goal is to recruit someone for something. Whether it is respect, product, and / or service depends on the way of presentation as well as depends on the way how to formulate the possible information. But we have to be careful not to overdrive in anything. Even in something as banal/cheaply as it is advertising, to avoid happening, as it was claimed by THE GUARDIAN (Sir Sorrell, 2012) as he is not convinced, that FACEBOOK will succeed as a good advertising medium. Yes, I might agree with the above because, on one side, we have a social network that focuses on information and communication, but also vice versa on the one hand, and on the other hand someone wants to turn it into an advertising medium. Still, realistically speaking, even if we agree with the above mentioned, do today, as communication is all within the study of the media, and is that all is advertising, or advert, regardless if he do it on the social and / or business binary way? Yes, I think that we can keep on one and the other as interactive forms of identical intents/purposes. Regardless if we would like to shape it as basic communication or something else. The only problem is if it happens to us as with the photo that is in front of you. And where do not you know if you're up or down.

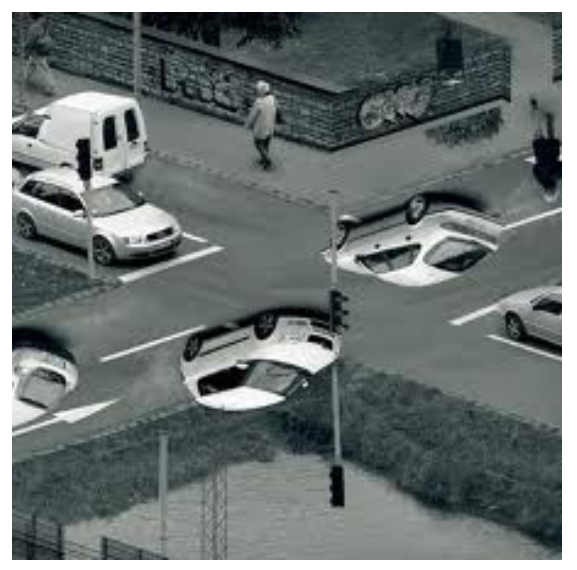

Photo 1. (what is reality?) ${ }^{18}$

18 Photo by Erik Johansson, http:/ / hypenotice.com/artwork/photo-manipulations-by-erik-johansson/11/ (6.04.2020). 
The fact that FACEBOOK as a social network has really created the preconditions for becoming a medium of the socialization message, but the message of socialization of the media as well, however, leads us into doubts if we perform a comparative analysis of the journalistic stigma, which is, in this case, realized through online journalism on social networks. What are we facing?

Table 1. Online journalism on social networks - In general vs. In particular

\begin{tabular}{|c|c|}
\hline $\begin{array}{l}\text { ONLINE JOURNALISM } \\
\text { IN GENERAL (Craig, 2005) }\end{array}$ & $\begin{array}{l}\text { JOURNALISM ON SOCIAL NETWORKS } \\
\text { IN PARTICULAR (Hadžialić, 2020) }\end{array}$ \\
\hline $\begin{array}{l}\text { The online audience of the news, in many re- } \\
\text { spects, looks more like the audience of special- } \\
\text { ized cable channels than on a radio or TV au- } \\
\text { dience. }\end{array}$ & $\begin{array}{l}\text { The online social media audience is already in } \\
\text { the fact that it is able to cover literary all in a favor/ } \\
\text { advantage of classical online journalism for which } \\
\text { we need to focus on a particular link - in this case, } \\
\text { on the posts are links to everyone, for all, and ev- } \\
\text { erywhere. }\end{array}$ \\
\hline $\begin{array}{l}\text { Online news creates a team (journalist, web } \\
\text { designer, editorial board). } \\
\text { Understandably, susceptible, accurately (de- } \\
\text { pending on the respect of the basic postulates } \\
\text { of the journalist profession - ethics, codex } \\
\text { and morals). }\end{array}$ & $\begin{array}{l}\text { News on social networks creates an individu- } \\
\text { al / group and there is no respect for the basic } \\
\text { postulates of the journalistic profession (ethics, } \\
\text { codex, morality), but only indications of future } \\
\text { constraints and warnings, and we know that after } \\
\text { the execution of some (evil)act and/or crime it is } \\
\text { difficult to correct the curved river. }\end{array}$ \\
\hline $\begin{array}{l}\text { Informing at the moment of the event happe- } \\
\text { ning with the possibility of placing live content } \\
\text { (video, audio, photo) }\end{array}$ & $\begin{array}{l}\text { Informing at the moment of the event with the pos- } \\
\text { sibility of placing live content (video, audio, pho- } \\
\text { to). And immediately, of course, we ask, where is } \\
\text { the catch } 22 \text { ? In the fact that information depends } \\
\text { on whether an educated journalist or uneducat- } \\
\text { ed manipulator placed the information on social } \\
\text { network - an individual / group with an aim of } \\
\text { focusing the public on a particular topic or news. }\end{array}$ \\
\hline $\begin{array}{l}\text { Interactivity of presented contents at the time } \\
\text { of placing of the information. Recognizing qua- } \\
\text { lity and reactions to it. }\end{array}$ & $\begin{array}{l}\text { Interactivity of presented contents at the time } \\
\text { of placing of the information. The problem with } \\
\text { (journalism on social networks lays within the fact } \\
\text { that it's not hard to write, it's hard to know how to } \\
\text { write (Hadžialić, 2010) }\end{array}$ \\
\hline $\begin{array}{l}\text { Creative thinking } \\
\text { (improvement of the ways of news reporting) }\end{array}$ & $\begin{array}{l}\text { Creative and recreational thinking (improvement, } \\
\text { but also so-called relaxing, recreational journalism } \\
\text { one to many and many to one) }\end{array}$ \\
\hline Focus on informing of the targeted audience & $\begin{array}{l}\text { Focus on informing of the targeted audience, but } \\
\text { also intermittent hitchikers (who are currently are } \\
\text { online and chat with the person who is just read- } \\
\text { ing and / or watching the presented online news) } \\
\text { of the news. }\end{array}$ \\
\hline
\end{tabular}


Benefits of media presenting or selling news over and through social networks (greater number of users, diversity of readers - levels of education, interests, gender) can often turn into flaws. Targeted? Maybe. Let's try to explain it methodologically. Yes, the fact is that socialization or the establishment of more social way of communicating on the Internet got its culmination through social networks, but at the same time presented us a mosaic of various forms of manipulation apriori and aposteriori, from the moment of presenting the news to the creation of what comes out from the direct use of the news.

\section{Southeast Europe as a modus vivendi of uneducated virtues}

Table 2. Journalism vs. and so call "journalism"

\begin{tabular}{|l|l|}
\hline \multicolumn{1}{|c|}{$\begin{array}{l}\text { JOURNALISM ON } \\
\text { SOCIAL NETWORKS }\end{array}$} & \multicolumn{1}{|c|}{$\begin{array}{c}\text { SO CALL ,IOURNALISM" } \\
\text { ON SOCIAL NETWORKS }\end{array}$} \\
\hline $\begin{array}{l}\text { News published via social networks about } \\
\text { the removal of the plates with Cyrillic } \\
\text { inscriptions from the buildings of state } \\
\text { institutions in Vukovar (Croatia), in Oc- } \\
\text { tober 2013 with the purpose of support- } \\
\text { ing this. }\end{array}$ & $\begin{array}{l}\text { The news is liked } \\
\text { nalism and yellow journalism on social networks) } \\
\text { atians) and shared with its own commentary across } \\
\text { the FACEBOOK with the aim of unifying as many } \\
\text { people as possible who thinks the same as the one } \\
\text { who started "sharing" the news. }\end{array}$ \\
\hline $\begin{array}{l}\text { News published via social networks about } \\
\text { the removal of the plates with Cyrillic in- } \\
\text { scriptions from the buildings of state in- } \\
\text { stitutions in Vukovar (Croatia), in Octo- } \\
\text { ber 2013 with the purpose of discrediting } \\
\text { the support of the mentioned. }\end{array}$ & $\begin{array}{l}\text { The news is liked } \\
\text { journalism and yellow journalism - read fake news - } \\
\text { on social networks) by a side of one national corps (in } \\
\text { this case - Serbians) and shared with its own commen- } \\
\text { tary across the FACEBOOK with the aim of unifying } \\
\text { as many people as possible who thinks the same as } \\
\text { the one who started sharing the news. }\end{array}$ \\
\hline $\begin{array}{l}\text { News published via social networks about } \\
\text { the removal of the plates with Cyrillic in- } \\
\text { scriptions from the buildings of state in- } \\
\text { stitutions in Vukovar (Croatia), in Octo- } \\
\text { ber 2013 with the purpose of traying to find } \\
\text { the solution for the problem. }\end{array}$ & $\begin{array}{l}\text { The news is liked } \\
\text { journalism and yellow journalism on social networks) } \\
\text { by a side of one national corps (in this case - both - } \\
\text { Croatians and Serbians) and shared with its own com- } \\
\text { mentary across the FACEBOOK with the aim of } \\
\text { unifying as many people as possible who thinks } \\
\text { the same as the one who started sharing the news. }\end{array}$ \\
\hline
\end{tabular}


The message as the medium of socialization - the media as the socialization message within social networks, regardless if we are talking about Facebook, Twitter, Pinterest, LinkedIn, Flickr, Instagram or any other online social network has brought to us, has undreamed possibilities of information, although also manipulation by presenting us the medium in its fullness - of demagogy. Remembering the Agoras by comparing this Square from Athens with the place of confronting the attitudes, opinions, news, videos and photos that we have on social networks, I would always have made decision for ... Agoras. Why? Agora was a direct talk face to one face, face to many faces and vice versa while for FACEBOOK it is possible that we have: a) A large number of false profiles on social networks with the aim of manipulating uneducated individuals; b) A large number of false, so-called test information before releasing information through our media to a targeted audience

Let's name just five common mistakes on social networks when we talk about journalism:

1. Incorrect measurement of the information presented through the number of likes and share. Namely, no matter how much our fans or all those who share our news online or share our news, we cannot know to what number of readers, listeners or viewers this news has reached, often because of the secretiveness of his / her friends, but also because of the fact that within his / her friend's group there may not be any interest in our news at all. In this case, he/she is here with us because of prestige (so that he/she can say in his groups that he/she is a follower and that he/she is sharing our news) and nothing more. Because it does not matter what your footprint is in the social network if your fans do not comment on your news and thus attract even those who would never read your news. In this way, if your fan comments, he also attracts friends from his/her circle who can be hooked on your posts not because of you, but because of his/her orientation towards you; 2. If we have our magazine/ newspaper and/or $\mathrm{TV} /$ radio channel, the most common mistake is to suddenly want to have a presentation of their media on all social networks that exist. It is far better to choose one or two, and on that social network have a permanent ability to place the information. If we open a bill to the many of it, we are lost in the maze of freshness and the inability to regularly update our information on all social networks; 3 . It is not enough just to place news / information and thus to meet the basic postulate of news and social media presentations. It is even necessary to have 
a person who will respond to comments on the social networks related to the actual news and perhaps in this way enable the editorial staff to further develop the news and create new information.; 4. Sociality is isolated in accordance with interest and therefore, regardless of whether we are the medium that is focused on particular topics and having its own audience, it is sometimes ok to step aside from our own public (social networks allow us that free of charge) and direct to the audience of different directions with the aim of gaining views and opinions about the presented news / information.; 5. There is a thought "that our destination is never a place but a new way of observing things" (Miller, 1891-1980). So our medium that use social networks must have a properly elaborated map of the road of behavior and creation of news / information on social networks. If we are only randomly present, with no targeted strategy of appearance it is difficult to attract the followers of our posts and thus the users of our information services.

\section{Conclusion}

Being convinced that social networks \& social media are the tools that can be of utmost importance for future forms of communication: a) Between individuals and individuals; b) Between individuals and groups; c) Between groups and communities and d) Among all the above. I believe that the above methodological assumptions, aimed at understanding the hypotheses set out in this paper, can be implemented in the environment/within social networks and social media of the virtual world, as well as in their closer and wider communication environment of the real world. The basic precondition for this is the play of general human emancipation through communication also on social networks and social media with the full moral responsibility of journalists and media messengers whose behavior has to be transmitted from traditional to new media according to the basic code and ethics of the profession (Hadžialić, 2014). The assumptions are there, but it will depend not only on individuals but also of becoming more serious as the wider community that the backbone of a social contract that we call the State are made of people and their particularities reflected through the groups or communities in which they live. Social Networks \& Social Media can be an extremely powerful tool for just 
something like that. If we use it in accordance with the methodological terms of this paper.

An nescis, wires me, quantila prudentia mundus regatur (Don't you know, my son, how little wisdom can be used to manage the world?) Exactly social networks and social media can be the driving force of directing, hoping, and ultimately intertwining virtual and real relationships of the individual, group, and/ or community, as far as we feel that we are far from it, bearing in mind the fact that we have long since passed from Gutenberg to the Hologram Galaxy. Why shouldn't we, then, tame it and make it, above all, human, just by using social networks \& social media.

\section{References}

\section{Literature}

Bort, J. (2016), The internet is still actually controlled by 14 people who hold 7 secret keys, http://www.businessinsider.com/the-internet-is-controlled-by-secretkeys-2016-10 (27.02.2020).

Chivers, T. (2009), Internet rules and laws: the top 10, from Godwin to Poe, http:/ / www .telegraph.co.uk/technology/news/6408927/Internet-rules-and-laws-the-top10-from-Godwin-to-Poe.html (27.03.2020).

Coen, V.d.V. (2015), Vukovar: Still divided by war, http://www.aljazeera.com/ indepth/features/2015/11/vukovar-divided-war-croatia-serbia-massacre-151120090853383.html (28.03.2020)

Craig, R. (2005), Online Journalism, (Belmont, USA: Thomson/Wadsworth).

Darrow, B(2017), LinkedIn claimshalfabillion users, http:/ / fortune.com/2017/04/24/ linkedin-users / (27.03.2020)

DeMers, J. (2014), The top 10 benefits of social media marketing - https://www .forbes.com/sites/jaysondemers/2014/08/11/the-top-10-benefits-of-social-media-marketing/\#6c2c15371f80 (accessed 1.04.2020).

Edwards, J. (2016), This conspiracy theory says ad tech companies deliberately keep web pages loading slow because they make more money that way, http://uk.businessinsider.com/conspiracy-web-pages-load-slowly-because-they-make-moremoney-that-way-2015-7 (1.04.2020).

From, E. (1994), Escape from Freedom, (New York, Holt).

Galagher, F. (2015), How many users does Google+ really have?, http:/ / www.techtimes .com/articles/51205/20150506/many-users-google-really.htm (3.04.2020). 
Global desktop web browser market share statcounter [graphic 1], http://gs.statcounter.com/ (6.04.2020).

Grainger, C. (2017), Is your Facebook obsession feeding a personality disorder?, http:/ / www.rd.com/advice/relationships/facebook-and-narcissism/ (3.04.2020).

Greenwood, S., A. Perrin, M. Duggan (2016), Social Media Update 2016, http:/ / www.pewinternet.org/2016/11/11/social-media-update-2016/ (4.04.2020).

Hadžialić, S. (2014), Bosnia and Herzegovina and XXI century, (Morrisville: Lulu Enterprises, Inc.).

Hosting Facts (2017), Internet Stats E Facts for 2017, https://hostingfacts.com/ internet-facts-stats-2016/ (4.04.2020).

Internet user distribution in the world - 2020 Q1 [graphic 3], http:/ / www.internetworldstats.com/stats.htm) (6.04.2020).

Internet World Penetration Rates by geographic regions - 2020 Q1 [graphic 2], http:/ / www.internetworldstats.com/stats.htm (7.04.2020).

Internet World Stats (2017), Internet Usage Statistics, The Internet Big Picture http:/ / www.internetworldstats.com/stats.htm (accessed 4.04.2020).

Johansson, E., [photo 1], http://hypenotice.com/artwork/photo-manipulations-by-erik-johansson/11/ (8.04.2020).

J. Robert Oppenheimer, http:/ / www.atomicheritage.org/profile/j-robert-oppenheimer.

Keller, J. (2010), When campaigns manipulate social media, http:/ / www.theatlantic.com/ politics/archive/2010/11/when-campaigns-manipulate-social-media/66351/ (4.04.2020).

Mayer, T. ( 2003), Mediokracija, medijska kolonizacija politike, (Zagreb: Fakultet Političkih Znanosti): 103.

Machiedo, M. (2013), Naše doba sliči mahnitom 17. stoljeću, „VIJENAC. Književni list za umjetnost, kulturu i znanost", 508-509: 4-6, http:/ / www.matica.hr/ vijenac/508/nase-doba-slici-mahnitom-17-stoljecu-22253/ (1.04.2020).

Markandeya, V. (2012), Computer scientist warns of social media manipulation in U.S. election, http://spectrum.ieee.org/telecom/internet/computer-scientist-warns-of-social-media-manipulation-in-us-election (5.04.2020).

Metcalf, S. (2017), Neoliberalism: the idea that swallowed the world, https://www. theguardian.com/news/2017/aug/18/neoliberalism-the-idea-that-changedthe-world (5.04.2020).

Miller, H. (1891-1980), Henry Miller > Quotes > Quotable Quote, https://www .goodreads.com/quotes/133768-one-s-destination-is-never-a-place-but-a-newway (4.04.2020).

NSA (2013), Using metadata to compile "social network diagrams" on Americans, http:/ / www.globalresearch.ca/nsa-using-metadata-to-compile-social-network-diagrams-on-americans/5352168 (1.04.2020). 
Otte, E., R. Rousseau (2002), Social network analysis: a powerful strategy, also for the information sciences, "Journal of Information Science" 28(6): 441-453, http:// journals.sagepub.com/doi/abs/10.1177/016555150202800601 (27.4.2020).

Rääbus, C (2017), Calls for Facebook to be more accountable for the rise in fear and hatred on social media,

http:/ / www.abc.net.au/news/2017-04-12/ rise-of-fear-and-hatred-on-facebookand-what-should-be-done/8433352 (27.04.2020).

Radio Free Europe (2013), Iranian authorities restore blocks on Facebook, Twitter, https://www.rferl.org/a/iran-social-media-facebook-twitter/25108565.html (6.04.2020).

Slade, H. (2014), The only email system the NSA can't access, https:/ / www.forbes.com/ sites/hollieslade/2014/05/19/the-only-email-system-the-nsa-cant-access / \#37f05a1c67f7 (6.04.2020).

Sorrell; M. (2012), Sir Martin Sorrell unconvinced that Facebook is a good advertising medium,

https://www.theguardian.com/media/2012/jun/21/martin-sorrell-unconvinced-facebook-advertising?utm_source=feedburner\&utm_medium=feed\&utm_campaign=Feed:+theguardian/media/rss+(Media) (6.04.2020).

Spinetti, L. (2016), 10 Essential rules for effective Facebook marketing in 2016, https:/ / www.webhostingsecretrevealed.net/blog/socialmedia-marketing/10-essential-rules-for-effective-facebook-marketing-in-2015/ (7.04.2020).

Special reports (2017), Digital in 2017: Global overview, https://wearesocial.com/ special-reports/digital-in-2017-global-overview (3.04.2020).

Taylor, Ch. (2011), Why not call it a Facebook revolution?, http:/ / edition.cnn.com/2011/ TECH/social.media/02/24/facebook.revolution/index.html (8.04.2020).

Tschabitscher, H. (2017), How many email users are there?, https:/ / www.lifewire. com/how-many-email-users-are-there-1171213 (6.04.2020).

UN (2016), War criminals in Balkans "not heroes", http:/ / www.unmultimedia.org/ radio/english/2016/03/war-criminals-in-balkans-not-heroes (6.04.2020).

Verisign (2017), Internet grows to 329.3 million domain name registrations in the fourth quarter of 2016, https://investor.verisign.com/releasedetail.cfm?release$\mathrm{id}=1015020(6.04 .2020)$.

Wikipedia (2017), Google+, https:/ / en.wikipedia.org/wiki/Google\%2B (6.04.2020). W3Schools, Most popular broswers, July 2017, https://www.w3schools.com/ Browsers/default.asp (2.04.2020).

\section{WWW sites re statistics}

Bankmycell, How many smartphones are in the world, https://www.bankmycell. com/blog/how-many-phones-are-in-the-world (7.04.2020).

Byers, K., How many blogs are there? (And 141 other blogging stats), https:/ / growthbadger.com/blog-stats/ (3.04.2020). 
Deyan, G. (2020), How many websites are there in 2021, https:/ / techjury.net/blog/ how-many-websites-are-there/\#gref (2.04.2020).

Facebook global user age distribution, https:/ / www.statista.com/statistics/376128/ facebook-global-user-age-distribution/ (7.04.2020).

Galov, N. (2020), 101+ web hosting stats and facts to help choose a better host, https:/ / hostingtribunal.com/blog/web-hosting-statistics/\#gref (3.04.2020).

Internet Live Stats, Twitter usage statistic, https://www.internetlivestats.com/ twitter-statistics/ (7.04.2020).

Internet World Stats, https:/ / www.internetworldstats.com/stats9.htm (6.04.2020).

Internet World Stats, Internet world penetration rates by geographic regions - 2020 Q1 http:/ / www.internetworldstats.com/stats.htm (6.04.2020).

Moore, M. (2020), Number of internet users APAC 2020 by country or region, https:/ / www.statista.com/statistics/265153/number-of-internet-users-in-the-asia-pacificregion/ (6.04.2020).

Number of monthly active Facebook users worldwide as of 4th quarter 2020, https:/ / www.statista.com/statistics/264810/number-of-monthly-active-facebook-users-worldwide/ (06.04.2020).

Number of social network users worldwide from 2017 to 2025 (in billions), https:/ / www.statista.com/statistics / 278414/number-of-worldwide-social-network-users/ (8.04.2020).

Osman, M., Mind-blowing LinkedIn statistic and facts, https://kinsta.com/blog/ linkedin-statistics/ (07.04.2020).

Reitnauer, T. (2009), How many domainsare registered in total? Statistics $\mathcal{E}$ numbers, part II, https:/ / iwantmyname.com/blog/how-many-domains-are-registered-intotal (02.04.2020).

Thomala, L. L. (2020), Number of internet user in China 2015-2025, https:// www.statista.com/statistics/278417/number-of-internet-users-in-china/ (6.04.2020).

WebsiteBuilder, Email marketing stats, https:/ / websitebuilder.org/email-marketing-stats/ (6.04.2020). 
